\title{
Isolation Of Snake-Head (Channa striata) Albumin Using Variation Concentration Of Hydrochloric and Citric Acid
}

\author{
Ika Kurniaty ${ }^{1}$, Erni Rita ${ }^{2}$, Giri Widakdo ${ }^{3}$, Tria Astika Endah Permatasari ${ }^{4}$, Mawar \\ Dwiyanti ${ }^{5}$ \\ \{ika.kurniaty@ftumj.ac.id ${ }^{1}$, erni_dika@yahoo.co.id², giriwae@gmail.com³ \\ tria_astika@yahoo.co.id ${ }^{4}$, mawardwiyantimawar@gmail.com ${ }^{5}$ \} \\ Universitas Muhammadiyah Jakarta, Indonesia
}

\begin{abstract}
Albumin is a type of sarcoplasmic protein that dissolves in low salt, acid, alkali solutions and water. One of the sources of albumin can be retrieved from snakehead fish. The distribution of snake-head extract and protein has been tried to increase levels of albumin in blood, wound healing process. The objective of this paper to specify the optimum of solvent concentration and albumin content from snake-head fish extraction. The method of this research used variation solvent concentration such as : chloride acid and citric acid solvent, temperature of extraction was set 600C. Albumin content was analyzed by High Performance Liquid Chromatography (HPLC) and protein soluble content was analyzed by method of Bradford. This paper obtained the result that the isolate of snake-head fish with the most upper albumin $(0.70 \%)$ was treatment by $0.25 \mathrm{M}$ of chloride acid solution with the most upper yield (8.6\%).
\end{abstract}

Keywords: Albumin, Extraction, Protein, Snake-head fish

\section{Introduction}

The extract of Snake-head (C. striata) protein is a source of nutrition that also has important functional properties for health and medicine[1]. Snake-head (Channa striata) is the name of a kind of freshwater predator fish Based on the region, this fish is known with different names such as Haruan (Melayu), Kutuk (Java), Kocolan (Betawi), and Bogo (Sunda)[2]. People in this areas know only common snakeheds (Channa striata) while the snakeheads possess several species [3].

In Indonesia local communities believe fish protein extracts are one of the altenative food that contains proteins of good quality due to rich with essential amino acids and plasma protein (sarcoplasmic) containing albumin [4], vitamin and mineral as antioxidant [5] for human health, well-being, process of wound healing [6], road accident, caesarian [7] and useful as a substitute of human serum albumin (HSA) that is still recently relatively expensive [8]. Albumin is a type of sarcoplasmic protein that be able to congealed by heat. It could be dissolves in low salt, acid, alkali solutions and water [9]. Albumin content of snakehead fish can be extracted using among solvents [10], [11].

In the present study, we determined the best of solvent concentration and the optimum content of albumin and protein from snake-head fish extraction. 


\section{Methods}

\subsection{Material and equipment}

Snakehead fish (Channa striata) in this reasearch came from traditional market in Indonesia such as Bekasi and Tangerang distric. This study also used hexane solvent to dissociate fat, aquades, chloride acid solutions $(0.05,0.1,0.15,0.2,0.25) \mathrm{M}$, and citric acid solutions $(0.1,0.15,0.2,0.25,0.3) \%$. Blender, knife, waterbath, pipette, centrifuge, oven, shaker, Spectrofotometer and High Performance Liquid Chromatography (HPLC) is equipment for this research.

\subsection{Research procedure}

Snakehead fish fillet without skin and bones used for this research. Wash the fillet fish and mash it using a blender. Then, add the various solvent with each of the solvent with ratio $100 \mathrm{ml}$ solutions : 50 gram of fish. This study used the various of solvent such as chloride acid solutions $(0.05,0.1,0.15,0.2,0.25) \mathrm{M}$, citric acid solutions $(0.1,0.15,0.2,0.25,0.3) \%$. The isolation process of fish protein is carried out with temperature $60^{\circ} \mathrm{C}$ in 15 minutes. Liquid and residue was separate after the filtered of each sample. Adding $25 \mathrm{ml}$ of hexane solvent into liquid, shaken it in 30 minutes and repeated one more time until two phase formed. After that, the oil phase from the sample was separated by funnel. Dried the exctract liquid at $50^{\circ} \mathrm{C}$ of the temperature for 12 hour in oven [10], [11]. There are two phases, extract liquid and protein coagulated. Protein coagulated was taken by centrifuge and dried.

\subsection{Samples Analyzing}

The analyzed of this studi was percentage of yield, total protein and albumin content from exctract Snakehead fish.

\subsubsection{Protein Content}

The method of Bradford for Snakehead fish protein analysis consists of two steps : Reagent. Coomassie brilliant blue G-250 as much as $10 \mathrm{mg}$ dissolved in $5 \mathrm{ml}$ of $95 \%$ ethanol. After that, add $10 \mathrm{ml}$ of $85 \%$ phosphoric acid. Finally, dilute the solution with distilled water up to $100 \mathrm{ml}$ [12], [13]. Procedure.(1) Protein solution of 10 and $100 \mu \mathrm{g}$ was put into a $100 \mu \mathrm{L}$ test tube. Dilution of the solution is carried out by comparison $(1,1: 10,1$ : 100, 1: 1000) if the sample concentration is unknown. (2) add $1 \mathrm{mg} / \mathrm{ml}$ standard protein solution with volumes of $10,20,40,60,80$, and $100 \mu \mathrm{L}$ put in a test tube and then add each of tube with $100 \mu \mathrm{L}$ aquadest. $100 \mu \mathrm{L}$ of aquadest was put into the test tube as an empty reagent (Sample for the calibration curve). (3) Mixed with vortemixing after adding $5 \mathrm{ml}$ of protein reagent to each tube. (4) measure the absorbance at $595 \mathrm{~nm} \mathrm{[2],} \mathrm{[13]}$

\subsubsection{Albumin Content}

The isolated standard from Snake-head Fish (C. striata) extract on the first step. A serial dilution of standard in the range $12.5-200 \mathrm{mg} / \mathrm{L}$ was prepared. The HPLC system used was waters protein separator Xbride TM BEH C4 3,5 $\mu \mathrm{m}(4,6 \times 250 \mathrm{~mm})$ column and UV $238 \mathrm{~nm}$ detector. For standard curve construction sample absorbance at $238 \mathrm{~nm}$ was recorded. Mobile phase gradient elution of $0.2 \mathrm{~mL} / \mathrm{min}$ was applied from $10 \%$ solvent $\mathrm{A}(0.1 \%$ trifluoroacietic acid in water) to $90 \%$ of solvent B ( $0.1 \%$ trifluoroacetic acid in acetonitrile) over $30 \mathrm{~min}$. For all analyses and standard curve construction a sample injection volume of $20 \mathrm{uL}$ was used. Determination of the concentration of each sample was achieved by comparison of values 
obtained from regression plot standard concentration curves and peak area of samples in resultant HPLC chromatograms [6], [14]

\subsubsection{Yield Content}

The yield of Snakehead fish protein content was calculated by the formulation as follow [15] :

Yield content $(\%)=\frac{\text { Result material weight }(g)}{\text { Raw material weight }(g)} \times 100 \%$

\section{Result And Discussion}

\subsection{Content of Yield}

Result of Snakehead protein isolate with two kind of solvent can be seen in Fig. 1 this below :

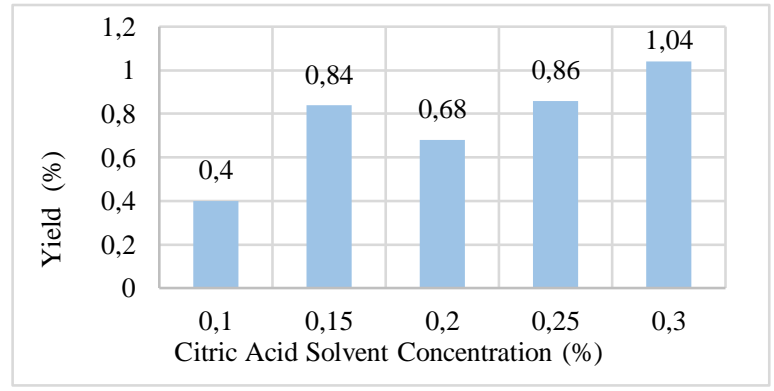

Fig. 1. Snake-head protein isolate of yield content by citric acid solvent concentration

Snake-head protein isolate of yield as presented in figure 1 showed that the optimum of yield was $1.04 \%$ with the extraction of citric acid solvent by heating at temperature $60^{\circ} \mathrm{C}$ in 15 minutes. The drying process causes decreased of the water content and yield from extract snake-head fish. The smaller water content causes decreased in the weight of the material water, because water on the extract is the primary component that affects the weight of the extract yield. If the water content is removed, the extract more compressed and lighter so that it will affected the final product of yield [16].

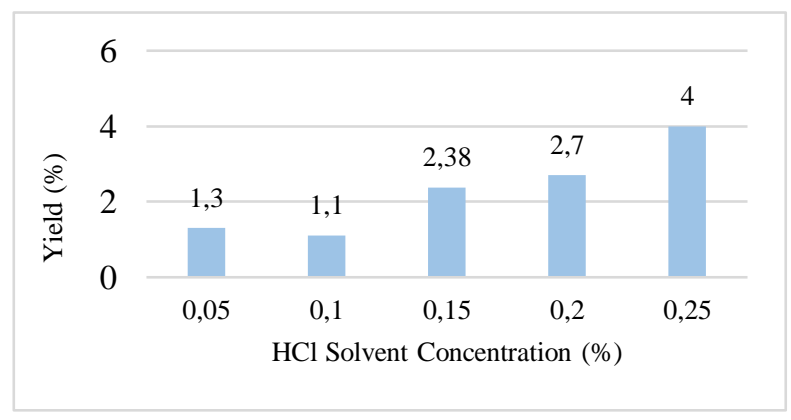

Fig. 2. Snakehead protein isolate of yield content by chloride acid solvent concentration 
The results of Fig 2 showed that the upper yield produced at $0.25 \mathrm{M}$ chloride acid concentration $(4 \%)$. The added of higher concentration of $\mathrm{HCl}$ solution during the extraction process of snakehead fish by heating (at temperature $60^{\circ} \mathrm{C}$ in 15 minutes ) produced a thicker filtrate solution. It was causes the filtrate was difficult to filter so that there was a possibility to many residues will passed, which was increases the weight of the product produced.

\subsection{Total protein Content}

Table 1. Protein Content Of Snakehead Protein Isolate By Chloride Acid Solvent Concentration

\begin{tabular}{ccc}
\hline HCl Concentration $(\mathbf{M})$ & Yield $(\boldsymbol{\%})$ & Protein content $(\%)$ \\
\hline $\mathbf{0 . 0 5}$ & 1.3 & 14.84 \\
$\mathbf{0 . 1}$ & 1.1 & 2.76 \\
$\mathbf{0 . 1 5}$ & 2.38 & 0.83 \\
$\mathbf{0 . 2}$ & 2.7 & 0.46 \\
$\mathbf{0 . 2 5}$ & 4 & 29.17 \\
\hline
\end{tabular}

The result of total protein content in table 1 presented that the upper of total protein content was $29.17 \%$ with $0.25 \mathrm{M}$ of chloride acid solvent treatment, whereas the lowest was by treatment $0.2 \mathrm{M}$ of chloride acid solvent by heating at temperature of $60^{\circ} \mathrm{C}$ for 15 minutes $(0.46 \%)$. According to protein content that shown in tables 1 and 2 were influenced by the size of snakehead fish that were not uniform as raw materials during the extraction process. it was produced a variety of protein content of Snakehead isolate

Table 2. Protein Content Of Snakehead Protein Isolate By Citric Acid Solvent Concentration

\begin{tabular}{ccc}
\hline Acid citric concentration (\%) & Yield (\%) & Protein content (\%) \\
\hline 0.1 & 0.4 & 2.97 \\
0.15 & 0.84 & 7.63 \\
0.2 & 0.68 & 3.05 \\
0.25 & 0.86 & 5.25 \\
0.3 & 1.04 & 9.45 \\
\hline
\end{tabular}

The result of total protein content on above presented that the optimum of total protein content was $9.45 \%$ by exctracted $0.3 \%$ of citric acid solvent, whereas the lowest was by extraction $0.1 \%$ of citric acid solvent with heating at temperature of $60^{\circ} \mathrm{C}$ for 15 minutes $(2.97 \%)$. Protein content is strongly influenced by the amount of solvent concentration. In table on above can be seen that the higher of protein content has the lower of water content [10] 


\subsection{Albumin content}

Table 3. Albumin Content Of Snakehead Protein Isolate By Chloride Acid Solvent Concentration

\begin{tabular}{cccc}
\hline HCl Concentration (M) & Yield (\%) & Protein content (\%) & Albumin Content (\%) \\
\hline 0.05 & 1.3 & 14.84 & Undetected \\
\hline 0.1 & 1.1 & 2.76 & Undetected \\
\hline 0.15 & 2.38 & 0.83 & Undetected \\
\hline 0.2 & 2.7 & 0.46 & Undetected \\
\hline 0.25 & 4 & 29.17 & 0.70 \\
\hline
\end{tabular}

Table 3 presented that the optimum of albumin content was $0.70 \%$ by Chloride Acid ( $\mathrm{HCl})$ $0.25 \mathrm{M}$ solvent treatment with heating at temperature $60^{\circ} \mathrm{C}$ for 15 minutes. The result of this study showed, albumin from extract snake-head fish is a spherical, globular protein that dissolve in high concentration of acid solution [11].

Table 4. Albumin Content of Snakehead Protein Isolate By Citric Acid Solvent Concentration

\begin{tabular}{cccc}
\hline $\begin{array}{c}\text { Acid citric } \\
\text { concentration }(\%)\end{array}$ & Yield $(\%)$ & Protein content $(\%)$ & Albumin Content $(\%)$ \\
\hline 0.1 & 0.4 & 2.97 & Undetected \\
0.15 & 0.84 & 7.63 & Undetected \\
0.2 & 0.68 & 3.05 & Undetected \\
0.25 & 0.86 & 5.25 & Undetected \\
0.3 & 1.04 & 9.45 & Undetected \\
\hline
\end{tabular}

Based on the data that shown in table 3 and 4 that the albumin content was produced from the extraction process by high strong acid concentration $(0.25 \mathrm{M}$ of $\mathrm{HCl}$ Solution) with heating. That was contrary to the theory that albumin can be produced from dilute acidic solutions. The results of yield, quality of protein, albumin content that shown in this article vary greatly. Many influencing factors such as fish type, solvent type, extraction method, temperature, filtering, drying, cutting meat of snakehead fish, weight of fish [17] . According to [18] The protein and albumin content in fish meat is influenced by the type of food, habitat, as well as food availability, but doesn't by sex differences. This research used snake-head fish from tradistional market in Bekasi dan Tangerang district, therefore, that the level of stress and the natural conditions of the environment fish lives very influencial to the high of albumin content [17].

\section{Conclusion}

This paper showed that the optimum of albumin $(0.70 \%)$, total protein content $(29,17 \%)$ with $4 \%$ of yield. The best pretreatment of this research with 0.25 Molarity of Chloride Acid solution by heat. Further research could be done to produce higher levels of 
albumin content from different types of snake-head fish and treatment by different concentrations, types of solvent and process methods.

\section{Acknowledgement}

Thank you to the Ministry of Technology Research and Higher Education of Indonesia who has provided financial support to the authors.

\section{References}

[1] M. Asfar, A. B. Tawali, and M. Mahendradatta, Potensi Ikan Gabus (Channa Striata) Sebagai Sumber Makanan Kesehatan- Review, Pros. Semin. Nas. Teknol. Ind. II, vol. 6, no. January, pp. 150-154, (2014) [Bahasa Indonesia].

[2] P. Rahayu, F. Marcelline, E. Sulistyaningrum, M. T. Suhartono, and R. R. Tjandrawinata, Potential effect of striatin (DLBS0333), a bioactive protein fraction isolated from Channa striata for wound treatment, Asian Pac. J. Trop. Biomed., vol. 6, no. 12, pp. 1001-1007, (2016).

[3] Firlianty, Vacuum drying albumin powder of snakehead (Channa micropeltes) potential for wound healing from Central Kalimantan, Indonesia, Int. J. ChemTech Res., vol. 9, no. 5, pp. 263-269, (2016).

[4] A. Mustafa, M. A. Widodo, and Y. Kristianto, Albumin And Zinc Content Of Snakehead Fish (Channa striata) Extract And Its Role In Health, IEESE Int. J. Sci. Technol., vol. 1, no. 2, pp. 1-8, (2012).

[5] D. Pudjonarko, Retnaningsih, and Z. Abidin, Clinical Outcome And Arginine Serum of Acute Ischemic Stroke Patients Supplemented by Snakehead Fish Extract, IOP Conf. Ser. Earth Environ. Sci., vol. 116, p. 012028, Feb. (2018).

[6] H. I. Januar, N. D. Fajarningsih, D. S. Zilda, A. Bramandito, and A. D. Wright, Concentration of fish serum albumin (FSA) in the aqueous extract of Indonesian Perciformes fishes muscle tissue, Nat. Prod. Res., vol. 29, no. 23, pp. 2230-2232, (2015).

[7] L.-H. Gam, C.-Y. Leow, and S. Baie, Proteomic Analysis of Snakehead Fish ( Channa striata ) Muscle Tissue, Malaysian J. Biochem. Mol. Biol., vol. 14, pp. 25-32, (2006).

[8] E. Suprayitno, H. Nursyam, and A. Mustafa, Chemical Composition and Amino Acid Profile of Channidae Collected From Central Kalimantan , Indonesia, vol. 2, no. 4, pp. 25-29, (2013).

[9] R. J. Fitzgerald et al., Extraction of Protein from Hoki and Barracouta Fish Heads for Utilisation as Functional Ingredients, J. Food Eng., vol. 23, no. 4, pp. 571-578, (2014).

[10] A. R. Romadhoni, E. Afrianto, and R. I. Pratama, Extraction of snakehead fish [ophiocephalus striatus (Bloch, 1793)] into fish protein concentrate as albumin source using various solvent, J. Teknol., vol. 78, no. 4-2, pp. 1-6, (2016).

[11] M. Asfar, A. B. Tawali, N. Abdullah, and M. Mahendradatta, Extraction Of Albumin Of Snakehead Fish ( Channa Striatus ) In Producing The Fish Protein Concentrate ( FPC ), Int. J. Sci. Technol. Res., vol. 3, no. 4, pp. 85-88, (2014).

[12] R. V. Nouroozi, M. V. Nouroozi, and M. Ahmadizadeh, Determination of Protein Concentration Using Bradford Microplate Protein Quantification Assay, Int. Electron. J. Med., vol. 4, no. 1, pp. 11-17, (2015).

[13] J. M. Walker, Handbook Edited by, vol. 3, no. 2. 2002.

[14] R. Susilowati and E. Chasanah, Nutritional And Albumin Content Of Swamp Fishes From Merauke, Papua, Indonesia, vol. 11, no. 3, pp. 107-116, (2016).

[15] V. V. G. A. B. M. B. S. Ramakrishnan, Extraction of Proteins from Mackerel Fish Processing Waste Using Alcalase Enzyme, J. Bioprocess. Biotech., vol. 03, no. 02, 
(2013).

[16] E. Yuniarti, Desi Windia; Suliyati, Titik Dwi; Suprayitno, Pengaruh Suhu Pengeringan Vakum Terhadap Kualitas Serbu Albumin Ikan Gabus (Ophiocephalus striatus), vol. 1, no. 1, pp. 55-60, (2013) [Bahasa Indonesia].

[17] A. N. Asikin and I. Kusumaningrum, Karakteristik Ekstrak Protein Ikan Gabus Berdasarkan Ukuran Berat Ikan Asal DAS Mahakam Kalimantan Timur, J. Pengolah. Has. Perikan. Indones., vol. 21, no. 1, p. 137, (2017) [Bahasa Indonesia].

[18] E. Chasanah, M. Nurilmala, A. R. Purnamasari, and D. Fithriani, Komposisi Kimia, Kadar Albumin dan Bioaktivitas Ekstrak Protein Ikan Gabus (Channa striata) Alam dan Hasil Budaya, JPB Kelaut. dan Perikan., vol. 10, no. 2, pp. 123-132, (2015) [Bahasa Indonesia]. 